ROCZNIKI NAUK PRAWNYCH

Tom XXX, numer $4-2020$

DOI: https://doi.org/10.18290/rnp20304-3

PIOTR KONIK

\title{
UMOWNE WYŁĄCZENIE I OGRANICZENIE WIERZYCIELSKIEGO OBOWIĄZKU WSPÓŁDZIAŁANIA PRZY WYKONYWANIU ZOBOWIĄZANIA
}

\section{WPROWADZENIE}

Wykonywanie zobowiązania nie jest sferą wyłącznej aktywności dłużnika. Choć to jego rola pozostaje tu dominująca, przy wykonywaniu zobowiązania uczestniczyć może także wierzyciel, a często jego udział jest wręcz nieodzowny. Najogólniejszym źródłem obowiązku ${ }^{1}$ w tym zakresie jest art. 354 § Kodeksu cywilnego ${ }^{2}$ przewidujący, że wierzyciel powinien współdziałać przy wykonywaniu zobowiązania z uwzględnieniem treści zobowiązania i w sposób odpowiadający jego celowi społeczno-gospodarczemu, zasadom współżycia społecznego oraz ustalonym zwyczajom. Obowiązek ten jest ujęty bardzo ogólnie i jest możliwy do skonkretyzowania (wymaga skonkretyzowania) dopiero na gruncie konkretnego zobowiązania ${ }^{3}$. Obok podanego przepisu, ustawodawca przewiduje także szereg regulacji, które dotyczą konkretnych przypadków współdziałania. Wskazać można w szczególności odnoszący się do wszystkich zobowiązań lub pewnych ich rodzajów obowiązek przyjęcia świadczenia (art. $356 \S 2$ k.c., art. 450 k.c., art. $518 \S 2$ k.c.), a także taki obowiązek występujący na gruncie poszczególnych stosunków z umów nazwanych (art. 535 § 1 k.c., art. 605 k.c.,

Dr PIOTR KonIK - adiunkt, Katedra Prawa Cywilnego i Handlowego, Wydział Prawa Uniwersytetu w Białymstoku, ul. A. Mickiewicza 1, 15-213 Białystok; e-mail: p.konik@uwb.edu.pl. ORCID: https://orcid.org/0000-0001-7766-2887.

${ }^{1}$ A. KLEIN (Skutki prawne braku wspótdziałania wierzyciela z dtużnikiem, „Acta Universitatis Wratislaviensis", Prawo 1990, t. CLXXXVI, nr 1152, s. 155, 156) wskazuje jednak wątpliwości dotyczące charakteru prawnego współdziałania, tj. czy jest ono objęte powinnością, obowiązkiem czy tylko uprawnieniem.

${ }^{2}$ Ustawa z dnia 23 kwietnia 1964 r. - Kodeks cywilny, tekst jedn. Dz.U. 2020, poz. 1740 [dalej: k.c.].

${ }^{3}$ P. Machnikowski, Struktura zobowiazania, [w:] System Prawa Prywatnego, t. V: Prawo zobowiązań - część ogólna, red. K. Osajda, Warszawa: C.H. Beck 2020, s. 167. 
art. 613 k.c., art. 620 k.c., art. 643 k.c., art. 647 k.c., art. 654 k.c.). Obok tego regulowane są także obowiązki dotyczące innych, niż przyjęcie świadczenia zachowań wierzyciela, w szczególności polegających na: wydaniu pokwitowania (art. 462 k.c.), udzieleniu informacji (art. $760^{2} \S 2$ k.c.) $)^{4}$, zachowaniu lojalności wobec drugiej strony (art. 760 k.c.) $)^{5}$, dostarczeniu materiałów do wykonania dzieła (art. 633 k.c.), przekazaniu terenu budowy i dostarczeniu projektu (art. 647 k.c. $)^{6}$, zapłacie zaliczki na wydatki (art. 743 k.c.), zwrocie przedmiotu świadczenia w przypadku świadczeń polegających na oddaniu wierzycielowi rzeczy lub sumy pieniężnej do używania przez pewien czas (art. 675 k.c., art. 705 k.c., art. 718 k.c., art. 723 k.c.) $)^{7}$, czy określonym postępowaniu przez wierzyciela z przedmiotem należnego mu świadczenia (art. 662 § 2 k.c., art. 666 $\S 1$ k.c., art. $709^{7}$ k.c. $)^{8}$. Obowiązki te określa się mianem obowiązków wierzycielskich $^{9}$, a zachowania wierzyciela podjętego w ich wykonaniu nie traktuje się jako jego świadczenia ${ }^{10}$.

W obliczu wynikającej z art. $353^{1}$ k.c. swobody kształtowania treści zobowiązania, pojawia się pytanie o dopuszczalność ingerencji umownej w sferę obowiązku wierzycielskiego współdziałania, a konkretnie o możliwość wyłączenia tego obowiązku bądź jego ograniczenia. W przypadku odpowiedzi pozytywnej zaistnieje zaś konieczność odpowiedzi na pytanie, czy takie wyłączenie bądź ograniczenie wpływa na sytuację dłużnika w ten sposób, że zostaje on obarczony obowiązkiem zachowań obciążających pierwotnie wierzyciela, a także, czy może on zostać obarczony takim obowiązkiem umownie.

\footnotetext{
${ }^{4}$ Ogólny obowiązek (tj. występujący na gruncie wszystkich zobowiązań) udzielania informacji przez wierzyciela wyprowadza się wprost z art. 354 § 2 k.c., tak np. W. BORYSIAK, Komentarz do art. 354 k.c., [w:] Kodeks cywilny. Komentarz. Zobowiąania. Część ogólna, t. III A, red. K. Osajda, Warszawa: C.H. Beck 2017, s. 76.

${ }^{5}$ Ogólny obowiązek, tj. występujący na gruncie wszystkich zobowiązań, zachowania lojalności przez wierzyciela wyprowadza się wprost z art. $354 \S 2$ k.c., tak np. F. BŁACHUTA, Komentarz do art. 354 k.c., [w:] Kodeks cywilny. Komentarz, t. II, red. Z. Resich, Warszawa: Wydawnictwo Prawnicze 1972, s. 849; M. SAFJAn, Komentarz do art. 354 k.c., [w:] Komentarz. Kodeks cywilny, t. I, red. K. Pietrzykowski, Warszawa: C.H. Beck 2015, art. 354, Nb 15; P. MACHNIKOwsKI, Komentarz do art. 354 k.c., [w:] Kodeks cywilny. Komentarz, red. E. Gniewek, P. Machnikowski, Warszawa: C.H. Beck 2016, art. 354, Nb 8; W. BorYsiaK, Komentarz do art. 354 k.c., [w:] Komentarz, red. K. Osajda, 2017, s. 76

${ }^{6}$ Zob. też wyrok SA w Katowicach z 24.09.2013 r., I ACa 549/13, LEX 1391905.

${ }^{7}$ Tak P. MACHNIKOwsKi, Struktura zobowiazania, s. 169.

${ }^{8}$ Tamże.

${ }^{9}$ A. KLEIN (Skutki prawne braku wspótdziałania, s. 156-157) postuluje też posługiwanie się pojęciem ,powinności wierzyciela” z uwagi na brak możliwości ich realizacji na drodze przymusowej (s. 157, 165). Pojęcie obowiązku i powinności są przez tego autora używane zamiennie (np. s. 156).

${ }^{10}$ A. KLEIN, Skutki prawne braku wspótdziatania, s. 155; Z. RADWAŃSKI, Zobowiąania - część ogólna, Warszawa: C.H. Beck 2003, s. 297.
} 


\section{WYŁĄCZANIE OBOWIĄZKU WSPÓŁDZIAŁANIA}

Kwestia umownej ingerencji stron w sferę obowiązku współdziałania z dłużnikiem przy wykonywaniu zobowiązania nie była przedmiotem szczególnej uwagi i analizy zarówno w doktrynie, jak i w orzecznictwie. Z wypowiedzi wyraźnie formułowanych w piśmiennictwie wynika dopuszczalność umownej ingerencji w tę sferę, polegającej na uszczegółowieniu obowiązków ustawowych, ich złagodzeniu, a nawet zniesieniu wierzycielskiego obowiązku współdziałania i przeniesieniu ciężaru starań o wykonanie zobowiązania w całości na dłużnika ${ }^{11}$. Przy czym pogląd co do dopuszczalności wyłączenia omawianego obowiązku nie został sformułowany w sposób kategoryczny, ale rozwiązanie to przedstawiono jako takie, którego nie można z góry wykluczyć i przy którym konieczne jest uwzględnienie granic swobody umów ${ }^{12}$. W odniesieniu do wyłączenia obowiązku współdziałania sformułowano jednak także zastrzeżenia i pogląd o niedopuszczalności takiego zabiegu ${ }^{13}$. Wskazuje się także na niedopuszczalność wyłączania konkretnych obowiązków, np. lojalności ${ }^{14}$. Kwestia ta wymaga więc bardziej wnikliwej analizy, z uwzględnieniem rozważań co do kryteriów ograniczających swobodę kontraktową wskazanych w art. $353^{1}$ k.c.

\subsection{Kryterium ustawy}

W pierwszej kolejności rozpatrzyć trzeba kryterium ustawy, co wymaga określenia charakteru przepisu (normy) z art. $354 \S 2$ k.c. W doktrynie i orzecznictwie kwestia ta nie była analizowana. Próbując ustalić imperatywny bądź dyspozytywny charakter tego przepisu (normy) i badając wartości, których ochronie on służy, od razu trzeba wyłączyć tezę, że chodzi tu o ochronę interesu wierzyciela. W doktrynie wskazuje się wprawdzie na specyficzny charakter obowiązku współdziałania, jako obowiązku nałożonego na wierzyciela w zasadzie $\mathrm{w}$ jego własnym interesie związanym $\mathrm{z}$ otrzymaniem świadczenia ${ }^{15}$, który to

\footnotetext{
${ }^{11}$ P. Machnikowski, Treść umowy, [w:] System Prawa Prywatnego, t. V, s. 572-573, Nb 21; M. Gutowski, Komentarz do art. 354 k.c., [w:] Kodeks cywilny, t. II: Komentarz. Art. 353-688, red. M. Gutowski, Warszawa: C.H. Beck 2019, art. 354, Nb 41; W. BorysiaK, Komentarz do art. 354 k.c., [w:] Komentarz, red. K. Osajda, 2017, s. 77.

${ }^{12}$ P. Machnikowski, Treść umowy, s. 572-573, Nb 21.

${ }^{13}$ W. BORYSIAK, Komentarz do art. 354 k.c., [w:] Komentarz, red. K. Osajda, 2017, s. 77.

${ }^{14}$ Tamże, s. 76.

${ }^{15}$ A. KLEIN, Skutki prawne braku wspótdziałania, s. 156-157; P. MACHNIKOWSKI, Struktura zobowiązania, s. 168, Nb 105.
} 
obowiązek nie podlega egzekucji i przymusowej realizacji przez dłużnika ${ }^{16}$, jednak znaczące jest spostrzeżenie, że wyłączenie przez strony obowiązku współdziałania nie wykluczałoby możliwości działania wierzyciela w tym zakresie. Wymuszanie zaś na wierzycielu normą prawną dbania o własny interes nie wydaje się racjonalne. Należy natomiast zgodzić się, że art. 354 § 2 k.c. ma na celu ochronę interesu dłużnika ${ }^{17}$. Dzięki współdziałaniu wierzyciela dłużnik może mieć możliwość zwolnienia się z zobowiązania, zwłaszcza wtedy, gdy zachowanie wierzyciela jest konieczne i nie można zastąpić czy uzupełnić go w inny sposób. Wartością chronioną w tym wypadku byłby więc przede wszystkim interes dłużnika, który również może uzasadniać zakwalifikowanie przepisu (normy) jako imperatywnego, jeżeli jednocześnie waga chronionego tu dobra byłaby większa, niż waga dobra, jakim jest wolność kontraktowa ${ }^{18}$. Dopuszczenie możliwości wyłączenia obowiązku współdziałania przez wierzyciela prowadziłoby de facto do pozostawienia uznaniu wierzyciela czynności od niego zależnych, a mogących mieć istotny wpływ na wykonanie zobowiązania. W rezultacie samo wykonanie zobowiązania mogłoby zostać uzależnione od jego woli. Dłużnik zaś, w zależności od wpływu (znaczenia) współdziałania wierzyciela na jego świadczenie, mógłby mieć problem z rozpoczęciem wykonywania zobowiązania (gdy współdziałanie byłoby konieczne na początkowym etapie wykonywania) albo z jego zakończeniem (gdy zachowanie wierzyciela polegałoby na odbiorze świadczenia). Zobowiązanie utrzymywałoby się jednak wtedy w mocy, a tym samym dłużnik pozostawałby obarczony obowiązkami, nie mogąc jednocześnie wygasić jednostronnie stosunku zobowiązaniowego i osiągnąć celu zobowiązania. Musiałby w nim pozostawać. Można mieć uzasadnioną wątpliwość, czy ustawodawcy chodziło o dopuszczenie do powstawania tego typu sytuacji, co może przemawiać za imperatywnym charakterem wspomnianej regulacji kodeksowej.

Wniosek ten osłabiany jest jednak przez spostrzeżenia płynące $\mathrm{z}$ analizy sytuacji dłużnika, jaka powstaje w wyniku wyłączenia wierzycielskiego obowiązku współdziałania wyrażonego w art. 354 § 2 k.c. Już na wstępie tego wątku należy zauważyć, że skutki postanowienia umownego wprowadzającego

\footnotetext{
${ }^{16}$ A. KLEIN, Elementy zobowiazaniowego stosunku prawnego, Wrocław: PWN 1980, s. 55-56; TENŻE, Skutki prawne braku wspótdziatania, s. 157; Z. RADWAŃSKI, Zobowiązania, s. 297; P. MACHNIKOWSKI, s. 168.

${ }^{17}$ M. GAWRYSIAK, Wina jako przestanka zwtoki wierzyciela, „Ruch Prawniczy, Ekonomiczny i Socjologiczny" 1979, nr 1, s. 43. A. Klein (Skutki prawne braku wspótdziałania, s. 146) wskazuje natomiast, że chodzi tu o ochronę uzasadnionych interesów stron, choć powołuje w tym kontekście ogólnie cały art. 354 k.c.

${ }^{18}$ P. Machnikowski, Treść umowy, s. 599, Nb 99.
} 
omawiane rozwiązanie byłyby niejednolite i różne w zależności przede wszystkim od doniosłości współdziałania wierzyciela w danym zobowiązaniu. Przy zobowiązaniach ze świadczeniem polegającym na zaniechaniu, przy których współdziałanie wierzyciela postrzegane jest jako nieistotne ${ }^{19}$, wyłączenie tego obowiązku nie miałoby żadnej doniosłości, a sytuacja dłużnika nie uległaby w jakimkolwiek stopniu pogorszeniu. W pozostałych przypadkach mogłaby ona kształtować się różnie, z różnym stopniem wpływu na interes dłużnika. Czasami bez współdziałania wierzyciela dłużnik nie byłby w ogóle w stanie rozpocząć wykonywania zobowiązania, przy innych świadczeniach, gdzie współdziałanie wymagane jest dopiero na końcu wykonywania zobowiązania, dłużnik mógłby nie być w stanie sfinalizować tego wykonywania. Byłoby tak w przypadkach współdziałania przybierającego postać przyjęcia (odbioru) świadczenia. Dłużnik mógłby wtedy pozostać ze świadczeniem (jego przedmiotem) i wiążącym go nadal zobowiązaniem. Wpływ na sytuację dłużnika mógłby okazać się wtedy bardziej dotkliwy.

Oceniając sytuację dłużnika w przypadku wyłączenia przepisu (normy) $\mathrm{z}$ art. $354 \S 2$ k.c. istotne jest, że dłużnikowi mogą wtedy nadal przysługiwać środki ochrony, a co za tym idzie, wyłączenie przez strony obowiązku współdziałania nie musi „skazywać” dłużnika na pozostawanie w niekorzystnej sytuacji. W szczególności:

a) Nie przekreśla ono możliwości złożenia przez dłużnika przedmiotu świadczenia do depozytu sądowego. Artykuł 467 pkt 4 k.c. przewiduje bowiem takie uprawnienie, jeżeli z powodu innych (niż wskazane we wcześniejszej części przepisu) okoliczności dotyczących osoby wierzyciela, świadczenie nie może być spełnione. Uprawnienie do złożenia przedmiotu świadczenia do depozytu sądowego nie jest w tym przepisie powiązane z obowiązkiem współdziałania, a zatem wyłączenie tego obowiązku nie pozbawiłoby tego uprawnienia. Mogłoby to jednak nastąpić, o ile świadczenie byłoby kompletne, a jego przedmiot nadawałby się do takiego złożenia. Do pewnego stopnia dłużnik mógłby więc wyeliminować negatywne konsekwencje wyłączenia obowiązku współdziałania. Inaczej byłoby, gdyby brak współdziałania stał się przeszkodą do powstania przedmiotu świadczenia, a w rezultacie, także do spełnienia świadczenia, albo gdyby świadczenie nie nadawało się do złożenia do depozytu.

b) Wyłączenie art. $354 \S 2$ k.c. nie wyklucza też możliwości powołania się przez dłużnika na zwłokę wierzyciela. Przesłanki zwłoki przewidziane w art. 486

\footnotetext{
${ }^{19}$ M. GAWRYSIAK, Wina jako przestanka, s. 44.
} 
$\S 2$ k.c., choć powiązane z obowiązkiem współdziałania z art. 354 § 2 k.c. ${ }^{20}$, i pomimo tego, że przepis ten uznaje się za przewidujący konsekwencje przypadków braku współdziałania ${ }^{21}$, można uznać za ujęte autonomicznie ${ }^{22}$. Wobec brzmienia przepisu definiującego zwłokę wierzyciela, a nie odwołującego się do art. 354 § 2 k.c., wyeliminowanie ogólnego obowiązku współdziałania zdaje się nie pozbawiać możliwości powołania się zarówno na nieuzasadnione uchylanie się przez wierzyciela od przyjęcia świadczenia, jak i na takież odmawianie przez niego dokonania czynności, bez której świadczenie nie może być spełnione. Tym bardziej byłoby to dopuszczalne w przypadku pozbawionego uzasadnienia oświadczenia, że świadczenia nie przyjmie, który postrzega się także, jako zupełnie oderwany od współdziałania ${ }^{23}$. Wniosek ten byłby aktualny nie tylko w odniesieniu do konsekwencji w postaci złożenia przedmiotu świadczenia do depozytu, ale także konsekwencji odszkodowawczych, które przecież mogą być ujęte odmiennie, niż w przypadku odpowiedzialności odszkodowawczej dłużnika, gdzie naruszenie zobowiązania (obowiązków dłużnika) jest co do zasady konieczne. Trzeba jednak przyznać, że kwestia wpływu wyłączenia obowiązku współdziałania na zwłokę wierzyciela nie jest zupełnie wolna od wątpliwości.

c) Należy też spostrzec, że wyeliminowanie ogólnego obowiązku współdziałania wierzyciela przy wykonywaniu zobowiązania nie uchyla możliwości powołania się przez dłużnika - w przypadku, gdyby w dalszej kolejności doszło do niewykonania lub nienależytego wykonania przez niego zobowiązania - na okoliczności dotyczące wierzyciela, jeżeli one byłyby pierwotną przyczyną naruszenia zobowiązania. Dłużnik także wtedy mógłby uniknąć konsekwencji, które zależą od okoliczności, za które on ponosi odpowiedzialność (w szczególności konsekwencji zwłoki dłużnika ${ }^{24}$ ), powołując się właśnie na przyczynę

\footnotetext{
${ }^{20}$ M. LemKowsKi, Komentarz do art. 486 k.c., [w:] Kodeks cywilny, t. II: Komentarz. Art. 353-688, red. M. Gutowski, Warszawa: C.H. Beck 2019, art. 486, Nb 3-10.

${ }^{21}$ Tamże, art. 486, Nb 4. A. Klein (Skutki prawne braku wspótdziałania, s. 148) art. $486 \S 1$ k.c. traktuje jako normę przewidującą sankcję naruszenia obowiązku współdziałania, zastrzegając przy tym wyraźnie, że przepis ten „nie uzależnia kwalifikacji wskazanych stanów jako zwłoki wierzyciela od tego, by były one przedmiotem obowiązku współdziałania nałożonego na wierzyciela” (s. 145).

${ }^{22}$ Tak A. KLEIN, Skutki prawne braku wspótdziatania, s. 145; M. LEMKOwSKI, Komentarz do art. 486 k.c., [w:] Komentarz, red. M. Gutowski, 2019, art. 486, Nb 4.

${ }^{23}$ Tak M. Lemkowski, Komentarz do art. 486 k.c., [w:] Komentarz, red. M. Gutowski, 2019, art. $486, \mathrm{Nb} 5$.

${ }^{24}$ A. KLEIN, Skutki prawne braku wspótdziałania, s. 157; T. WIŚNIEWSKI, Komentarz do art. 486 k.c., [w:] Komentarz. Zobowiazania, t. I, red. G. Bieniek, 2002, s. 561; W. PopiOŁEK, Komentarz do art. 486 k.c., [w:] Komentarz, red. K. Pietrzykowski, 2018, art. 486, Nb 8; K. ZAGrobelNY, Komentarz do art. 486 k.c., [w:] Komentarz, red. E. Gniewek, P. Machnikowski, 2019, art. 486, Nb 7, który wskazuje, że wykluczone byłoby wtedy także przyjmowanie stanu opóźnienia; M. LEMKOwsKI,
} 
w postaci zachowania drugiej strony ${ }^{25}$. Gdyby zachowanie wierzyciela było tylko jedną z przyczyn niewykonania zobowiązania, po stronie dłużnika wchodziłoby w grę powołanie się na przyczynienie się wierzyciela ${ }^{26}$.

d) Doniosłość skutków wyłączenia obowiązku współdziałania znacząco minimalizuje także sam charakter obowiązku współdziałania, który postrzegany jest dość powszechnie, jako wprowadzony w interesie samego wierzyciela, a co za tym idzie, jako „osłabiony”, gdyż niepodlegający przymusowej realizacji (egzekucji) ${ }^{27}$. Oznacza to, że nawet gdyby obowiązek ten nie został wyłączony, a wierzyciel go i tak nie zrealizował, dłużnik nie miałby możliwości doprowadzenia do jego przymusowej realizacji. Sytuacja dłużnika także przy niewyłączonym obowiązku nie byłaby więc istotnie różna. Na marginesie należy zauważyć, że trafność przywołanej kwalifikacji tego obowiązku, wobec braku wyraźnej podstawy prawnej, budzi jednak wątpliwości i nie jest wykluczone stanowisko przeciwne, nakazujące rozpatrywać obowiązek współdziałania wierzyciela - pod względem przymusowej realizacji - analogicznie jak obowiązki dłużnika ${ }^{28}$. Przynajmniej w odniesieniu do części przypadków współdziałania oznaczałoby to możliwość przymusowego ich zrealizowania, a co za tym idzie, wyłączenie obowiązku współdziałania w tym zakresie oznaczałoby dla dłużnika pogorszenie sytuacji przez utratę możliwości przymusowej realizacji takiego współdziałania.

e) Wyłączenie ogólnego obowiązku współdziałania wyrażonego w art. 354 $\S 2$ k.c. byłoby w wielu przypadkach łagodzone przepisami przewidującymi szczególne obowiązki współdziałania, na istnienie których wyeliminowanie ogólnej regulacji nie ma automatycznego wpływu. Stąd wyłączenie tych szczegółowych obowiązków wymaga każdorazowo odrębnej analizy. Nie wdając się w rozważania szczegółowe zauważyć trzeba, że w takich przypadkach, jak

Komentarz do art. 486 k.c., [w:] Komentarz, red. M. Gutowski, 2019, art. 486, Nb 26; W. BoRYSIAK, Komentarz do art. 354 k.c., [w:] Komentarz, red. K. Osajda, 2017, s. 78. Odmiennie J.M. KondeK, Komentarz do art. 46 k.c., [w:] Komentarz, red. K. Osajda, 2017, s. 1137.

${ }^{25}$ Zob. A. KLEIN, Skutki prawne braku wspótdziatania, s. 157; TENŻE, Wykonanie umowy i odpowiedzialnośćl, [w:] Instytucje prawne w gospodarce narodowej, red. L. Bar, Wrocław-Warszawa-Kraków-Gdańsk-Łódź: Ossolineum 1981, s. 307; F. ZoLL, Wykonanie i skutki niewykonania lub nienależytego wykonania zobowiazań, [w:] System Prawa Prywatnego, t. VI: Prawo zobowiazań - czesść ogólna, red. A. Olejniczak, Warszawa: C.H. Beck 2016, s. 1271.

${ }^{26} \mathrm{~F}$. ZoLL, Wykonanie i skutki niewykonania lub nienależytego wykonania zobowiazań, s. 1271.

27 A. KLEIN, Elementy, s. 55-56; TENŻE, Skutki prawne braku wspótdziałania, s. 157; P. MACHNiKOWSKI, Struktura zobowiąania, s. 168.

${ }^{28} \mathrm{Z}$ obowiązkiem tym związane byłoby roszczenie zaskarżalne dłużnika. Przy współdziałaniu przybierającym postać czynności prawnych (a więc wymagających złożenia oświadczenia woli) można byłoby stosować art. 64 k.c., o ile charakter zastępowanej czynności prawnej na to by zezwalał. W odniesieniu do odbioru rezultatu robót budowlanych zob. P. KoNIK, Odbiór robót budowlanych - zagadnienia wybrane, „Studia Prawa Prywatnego” 2016, z. 2, s. 59-61. 
art. $535 \S 1$ k.c., art. 605 k.c., art. 613 k.c. czy art. 647 k.c. skonkretyzowany obowiązek współdziałania w postaci obowiązku odbioru świadczenia określony jest przez przepisy regulujące, tzw. essentiale negotii poszczególnych typów umów (sprzedaż, dostawa, kontraktacja, roboty budowlane), co wymaga przyjęcia imperatywnego charakteru tych przepisów (norm). Podobnie, i z podobnych względów, można by ocenić przewidziany w art. 647 k.c. obowiązek inwestora przekazania terenu budowy i dostarczenia projektu wykonawcy robót, choć kwestia ta budzi wątpliwości ${ }^{29}$. Kategoryczne brzmienie i wyraźna funkcja chroniąca interes dłużnika przemawia także za imperatywnym charakterem przepisów (norm) art. $356 \S 2$ k.c., art. 450 k.c. oraz art. $518 \S 2$ k.c., które wyraźnie wyłączają możliwość nieprzyjęcia świadczenia przez wierzyciela. Za imperatywny należałoby także uznać art. 643 k.c., formułujący obowiązek zamawiającego przyjęcia dzieła wydawanego mu przez wykonawcę zgodnie ze zobowiązaniem, co przy indywidualnym charakterze świadczenia chroni dłużnika przed podwyższonym ryzykiem pozostania $\mathrm{z}$ nieprzydatnym mu przedmiotem tego świadczenia. Charakter innych przywołanych na wstępie przepisów określających szczegółowe obowiązki wierzyciela dające się zmieścić w zakresie pojęcia współdziałania przy wykonywaniu zobowiązania, nie jest tak jednoznaczny i trudno kwalifikować je jako imperatywne czy semiimperatywne.

f) Należy także zauważyć, że wyłączenie obowiązku współdziałania mogłoby zostać powiązane $\mathrm{z}$ innymi postanowieniami umownymi, mogącymi łagodzić powstające z tego tytułu niedogodności. Na przykład mogłoby zostać jednocześnie przewidziane dla dłużnika uprawnienie do uzupełnienia braku zachowania wierzyciela przez samego dłużnika (np. dokonanie przez niego oznaczenia pewnego parametru świadczenia, czy stworzenie sytuacji równorzędnej z odbiorem ${ }^{30}$ ). Mogłoby zostać przyznane mu także uprawnienie do wygaszenia zobowiązania, np. uprawnienie do odstąpienia, choć ono uzasadnione byłoby raczej w sytuacjach, gdy braku zachowania wierzyciela nie dałoby się wypełnić zastępczo i gdy zapewniono wierzycielowi dodatkową szansę na wykonanie współdziałania.

Powyższe rozważania wskazują, że wyłączenie ogólnego obowiązku współdziałania nie miałoby jednolitego wpływu na wszystkie zobowiązania, co przy

\footnotetext{
${ }^{29}$ Pogląd, że dostarczenie projektu przez inwestora jest elementem przedmiotowo istotnym umowy o roboty budowlane, występuje dość powszechnie w orzecznictwie, zob. np. uchwała SN(7) z 11.1.2002 r., III CZP 63/01, OSP 2002, Nr 10, poz. 125, a także przegląd orzecznictwa przez J.A. StrZĘPKA, Umowa o roboty budowlane, [w:] System Prawa Handlowego, t. V: Prawo umów handlowych, red. M. Stec, Warszawa: C.H. Beck 2017, s. 1438-1445.

${ }^{30}$ Zob. w odniesieniu do odbioru przy robotach budowlanych P. KONIK, Odbiór robót budowlanych, s. 62 .
} 
jednoczesnej wielości czynników wpływających na sytuację dłużnika, powodowałoby trudność dokonania abstrakcyjnej oceny i kwalifikacji jednolitej wobec wszystkich przypadków (zobowiązań). Sytuacja dłużnika przy takim wyłączeniu nie musiałaby znacząco różnić się od tej, jaka istniałaby przy braku wyłączenia. Kwalifikowanie omawianego postanowienia umownego jako sprzecznego z ustawą budzi więc poważne wątpliwości. Wydaje się, że bardziej właściwe mogłoby się tu okazać kryterium pozwalające na ocenę indywidualnych rozwiązań, a za takie można uznać właściwość (naturę) zobowiązania.

Wątpliwości co do imperatywnego charakteru art. $354 \S 2$ k.c. nie muszą jednak oznaczać zupełnego wyłączenia kryterium ustawy. Rozpatrywać bowiem można w tym przypadku stosowanie art. $385^{1}$ k.c., choć tylko w zakresie podmiotowo-przedmiotowym $\mathrm{w}$ nim uregulowanym. Wyłączenie obowiązku współdziałania wierzyciela, którym jest przedsiębiorca, mogłoby prowadzić do ukształtowania sytuacji konsumenta, jako dłużnika w sposób sprzeczny z dobrymi obyczajami i prowadzący do rażącego naruszenia jego interesu, na co wskazują rozważania dotyczące kryterium ustawy. Przy zachowaniu pozostałych przesłanek $\mathrm{z}$ art. $385^{1} \S 1$ k.c. postanowienie umowne przewidujące wyłączenie wierzycielskiego obowiązku współdziałania mogłoby więc zostać uznane za klauzulę abuzywną. Wniosek ten uzyskuje wsparcie w treści art. $385^{3}$ k.c., gdzie w katalogu można odnaleźć postanowienia oparte na podobnej konstrukcji, tj. prowadzące do pozostawienia do uznania wierzyciela istotnych kwestii związanych z zobowiązaniem. Chodzi o pkt 8, przewidujący postanowienie uzależniające spełnienie świadczenia od okoliczności zależnych tylko od woli kontrahenta konsumenta, a także o pkt 11 przewidujący postanowienie przyznające tylko kontrahentowi konsumenta uprawnienie do stwierdzania zgodności świadczenia $\mathrm{z}$ umową. $\mathrm{W}$ rezultacie omawiane rozwiązanie umowne mogłoby być uznane za niewiążące konsumenta.

Wyłączenie ogólnego obowiązku współdziałania wierzyciela przy wykonywaniu zobowiązania, wyrażonego w art. $354 \S 2$ k.c., można by oceniać inaczej w przypadkach, w ktorych określone konsekwencje przewidziane dla wierzyciela przez ustawę mogłyby zostać uznane za uzależnione wprost od takiego obowiązku, a nie byłyby jednocześnie uzależnione od samodzielnych przesłanek.

\subsection{Kryterium właściwości (natury) zobowiązania}

Wątpliwości dotyczące kryterium ustawy w obrocie pozakonsumenckim skłaniają do rozważenia, czy postanowienie umowne wyłączające obowiązek współdziałania wierzyciela przy wykonywaniu zobowiązania nie pozostaje 
w sprzeczności z kryterium właściwości (natury) zobowiązania. Co do charakteru tego kryterium należy odesłać do szczegółowych rozważań w doktrynie i orzecznictwie $^{31}$. W kwestiach szczegółowych należy natomiast odnotować pogląd wskazujący, że za cechę charakterystyczną zobowiązania może być uznane to, że stosunek obligacyjny zapewnia ochronę podstawowych interesów obu stron. Chroni więc nie tylko interes wierzyciela, ale i uzasadniony interes dłużnika ${ }^{32}$. Ten zaś można dostrzec przede wszystkim w skutecznym doprowadzeniu do spełnienia świadczenia, i w rezultacie do wykonania zobowiązania i zwolnienia się z niego w sposób najbardziej zgodny z jego funkcją społeczno-gospodarczą. Dopuszczenie do tego, że dłużnik nie będzie mógł liczyć na współdziałanie wierzyciela, a właściwie, że współdziałanie to pozostawione byłoby do wyłącznego uznania wierzyciela, mogłoby doprowadzić do eliminacji tej cechy zobowiązania, a tym samym do znaczącego pozbawienia dłużnika ochrony jego interesu. Mogłoby to okazać się dotkliwe dla niego, zwłaszcza gdyby chodziło o współdziałanie przyjmujące postać zachowania możliwego do zrealizowania tylko przez wierzyciela, a więc niezastępowalnego. Uznaniowość odnosząca się przede wszystkim do przyjęcia świadczenia, mogłaby zaś dodatkowo powodować nadmierne uzależnienie dłużnika od wierzyciela, do czego stosunek zobowiązaniowy również nie powinien prowadzić3 ${ }^{33}$.

W końcu zauważyć trzeba, że wyłączenie obowiązku wierzycielskiego współdziałania, zwłaszcza jeżeli miałoby dotyczyć zachowań zależnych wyłącznie od wierzyciela, stawiałoby pod znakiem zapytania racjonalność tak ukształtowanego zobowiązania. Ustawodawca nieprzypadkowo wprowadza wierzycielski obowiązek współdziałania. Jest on wynikiem spostrzeżenia, że dłużnik nie zawsze ma wyłączny wpływ na wykonanie zobowiązania, i często jego zachowanie okazałoby się niewystarczające dla tego wykonania, oraz że często wykonanie zobowiązania zależy od okoliczności powiązanych ściśle ze sferą wierzyciela, a w szczególności dotyczących jego osoby czy zależnych od jego wiedzy lub woli. Stąd względy racjonalności przemawiają za przypisaniem do roli wierzyciela także takich zachowań, które mają umożliwić bądź ułatwić dłużnikowi wykonanie zobowiązania. Przy wyłączeniu obowiązku współdziałania, w niektórych przypadkach zachodziłoby pewne podobieństwo do wykreowania sytuacji ze

${ }^{31}$ Zob. M. SAFJAN, Komentarz do art. $353^{1}$ k.c., [w:] Komentarz, red. K. Pietrzykowski, 2018, art. $353^{1}$ k.c., Nb 14-21; R. TRZASKOWSKI, Granice swobody ksztattowania treści i celu umów obligacyjnych. Art. $353^{l}$ k.c., Kraków: Zakamycze 2005, s. 300 n.; P. MACHNikowski, Treść umowy, s. 610-616; P. KoNIK, Umowne ksztattowanie odpowiedzialności dtużnika za naruszenie zobowiazania w polskim prawie cywilnym, Warszawa: C.H. Beck 2019, s. 101-112 i podana tam literatura.

${ }^{32}$ R. TRZASKowski, Granice swobody, s. 349; P. KoniK, Umowne ksztattowanie, s. 189, 266.

${ }^{33}$ P. KoniK, Umowne ksztattowanie, s. 266. 
świadczeniem niemożliwym do spełnienia. Ów związek współdziałania z rolą wierzyciela w zobowiązaniu może dodatkowo uzasadniać uznanie tego wspó1działania, przynajmniej w przypadkach zależnych wyłącznie od woli wierzyciela, za samodzielną cechę charakterystyczną zobowiązania, która powinna być respektowana przy umownym kształtowaniu obowiązków stron. Nie ma ona jednak charakteru powszechnego, co dawałoby podstawę do wyodrębnienia rodzaju zobowiązań, przy których współdziałanie wierzyciela ma istotne znaczenie, oraz pozostałych.

Pomimo tego generalny wniosek o niedopuszczalności postanowienia umownego wyłączającego art. 354 § 2 k.c. z uwagi na sprzeczność z właściwością (naturą) zobowiązania należałoby uznać za zbyt ogólny. Przemawia za tym, już choćby wspominana wcześniej, różna doniosłość współdziałania w poszczególnych zobowiązaniach, powodująca, że jego eliminacja miałaby różny wpływ na zobowiązanie i sytuację w nim dłużnika, co trudno oceniać całościowo. Może to natomiast stanowić podstawę do wyróżnienia - na podstawie kryterium znaczenia współdziałania wierzyciela dla wykonywania zobowiązania - dwóch kategorii zobowiązań, tj. tych, w których współdziałanie jest konieczne, i pozostałych, które nie wykazują takiej konieczności. Ponadto trzeba tu uwzględnić uregulowania kodeksowe chroniące interes dłużnika w takiej sytuacji i przewidujące szczegółowe konsekwencje dla wierzyciela. W wielu przypadkach sytuacja dłużnika może więc nie wyglądać tak niekorzystnie, jak to przedstawiono, co wymaga każdorazowo szczegółowej analizy na gruncie każdego zindywidualizowanego zobowiązania. Dopiero na tej płaszczyźnie formułowane mogą być bardziej konkretne wnioski, co pokazuje też, że kryterium właściwości (natury) zobowiązania jest bardziej elastyczne niż kryterium ustawy. W tym kontekście można jednak stwierdzić, że postanowienia umowne wyłączające wierzycielski obowiązek współdziałania w tych przypadkach, gdy jest on nieodzowny i jednocześnie znoszące wszystkie bądź nawet większość konsekwencji aktualnie z nim wiązanych przez kodeks cywilny (o ile takie zniesienie byłoby w ogóle skuteczne), zasługiwałoby na jednoznacznie negatywną ocenę ${ }^{34}$.

\subsection{Zasady współżycia społecznego}

W doktrynie zakwestionowano dopuszczalność całkowitego wykluczenia obowiązku współdziałania wskazując, że postanowienie umowne eliminujące przewidziany $\mathrm{w}$ art. $354 \S 2$ k.c. w $\mathrm{zw}$. $\mathrm{z}$ art. $354 \S 1$ k.c. obowiązek

\footnotetext{
${ }^{34}$ Niezależnie od tego można zauważyć, że konstrukcja taka mogłaby być rozpatrywana w kontekście niemożliwości świadczenia.
} 
współdziałania wierzyciela w sposób zgodny z zasadami współżycia społecznego, samo musiałoby zostać uznane za sprzeczne z takimi zasadami i stąd za nieważne $^{35}$. Pogląd ten został sformułowany ogólnie, co utrudnia jego analizę. Jeżeli jednak opierał się on na wyobrażeniu, że w wyniku takiego wyłączenia powstaje sytuacja, w której wierzyciel może w trakcie wykonywania zobowiązania podejmować zachowania sprzeczne $\mathrm{z}$ względami słuszności i nie ponosić $\mathrm{z}$ tego tytułu żadnych konsekwencji, albo powodować konsekwencje jedynie dla dłużnika, to pogląd ten wydaje się zbyt kategoryczny. Jak pokazały bowiem rozważania dotyczące kryterium ustawy, pomimo wyłączenia ogólnego wierzycielskiego obowiązku współdziałania dłużnik zachowuje pewne możliwości ochrony swego interesu. Nie powstaje więc sytuacja, że dłużnik jest w całości zależny od woli wierzyciela i musi ponosić konsekwencje zachowań drugiej strony, która ich nie ponosi pomimo tego, że są one sprzeczne z zasadami współżycia społecznego (np. nieuczciwe czy krzywdzące). Dopiero stworzenie takiej sytuacji uzasadniałoby w mojej ocenie przyjęcie sprzeczności z omawianym kryterium. Konstrukcja taka budziłaby wątpliwości także na gruncie pozostałych kryteriów.

\section{OGRANICZANIE ZAKRESU OBOWIĄZKU WSPÓŁDZIAŁANIA}

Na gruncie art. $354 \S 2$ k.c. dotyczącego współdziałania wierzyciela przy wykonywaniu zobowiązania można dokonać podobnego rozróżnienia, jak w odniesieniu do dłużnika na gruncie art. 354 § 1 k.c., gdzie daje się rozdzielić konkretne obowiązki dłużnika wynikające z treści zobowiązania (co dłużnik ma zrobić) oraz kryteria określające sposób ich wykonania (jak dłużnik ma to zrobić). Możemy więc mówić o samym obowiązku wierzycielskiego współdziałania (jego treści, konkretnych szczegółowych zachowaniach, które wierzyciel ma podjąć), a także o sposobie jego zrealizowania, który ma być zgodny ze wskazanymi kryteriami ${ }^{36}$. W rezultacie ograniczenie obowiązku współdziałania może przybierać postać redukcji zakresu tego obowiązku, a zwłaszcza wyłączenia niektórych obowiązków szczegółowych, które można by wyodrębnić w ramach ogólnego obowiązku współdziałania, albo przez ograniczenie kryteriów określających, jak ten obowiązek ma być wykonywany, a wskazanych w art. 354 § 1 k.c.

\footnotetext{
${ }^{35}$ W. BORYSIAK, Komentarz do art. 354 k.c., [w:] Komentarz, red. K. Osajda, 2017, s. 77.

${ }^{36}$ Zauważyć jednak trzeba, że o ile takie rozróżnienie czysto teoretycznie (abstrakcyjnie) daje się przeprowadzić dość łatwo, o tyle w praktyce rozdzielenie obu tych sfer wydaje się poważnie utrudnione, o ile w ogóle możliwe. Wydaje się, że kryteria wskazane w art. 354 § 1 k.c. mogą czasami określać także, co wierzyciel ma zrobić w ramach współdziałania, a nie tylko, jak ma to zrobić.
} 
Odnośnie do pierwszej sfery należy zauważyć, że wcześniejsze ustalenie, iż wyłączenie ogólnego obowiązku współdziałania nie musi rodzić sprzeczności z kryterium ustawy, właściwościami (naturą) zobowiązania czy zasadami współżycia społecznego, prowadzi do wniosku (opartego na argumentacji a maiori ad minus), że w tych sytuacjach, w których wyłączenie ogólnego obowiązku współdziałania z art. $354 \S 2$ k.c. byłoby dopuszczalne, tym bardziej za dopuszczalne co do zasady można by uznać rozwiązanie polegające jedynie na ograniczeniu zakresu tego obowiązku. Przyjęcie niedopuszczalności jego wyłączenia nie przekreślałoby badania jego ograniczenia. W takim przypadku trzeba byłoby mieć na uwadze, czy konstrukcja ograniczenia nie prowadzi do tych samych konsekwencji, które zdecydowały o niedopuszczalności wyłączenia. Przyjęcie niedopuszczalności ograniczenia tego obowiązku przemawiałoby zaś za przyjęciem niedopuszczalności jego wyłączenia. Przy kształtowaniu regulacji umownej tego dotyczącej należałoby jednak uwzględnić kilka kwestii, a mianowicie:

a) Ponieważ treść zobowiązania kształtowana jest w odniesieniu do współdziałania wierzyciela głównie przez kodeks cywilny, stąd znaczenie będzie miała okoliczność istnienia ewentualnych szczegółowych regulacji kształtujących konkretne obowiązki w zakresie współdziałania wierzyciela. W rezultacie, skuteczność postanowień umownych zawężających obowiązek współdziałania zależeć może od charakteru poszczególnych przepisów (norm). Imperatywny charakter niektórych z nich (jak wyżej wskazano) wyłączy także możliwość ograniczania regulowanego przez nie obowiązku. W pozostałym zakresie szczególne znaczenie miałoby kryterium właściwości (natury) zobowiązania.

b) Konkretyzacja tego ograniczenia zależna jest od charakteru i treści danego zobowiązania oraz wyjściowego zakresu współdziałania wierzyciela rekonstruowanego przede wszystkim na podstawie regulacji kodeksowej oraz umownej. Możliwa jest więc ona dopiero przy uwzględnieniu konkretnych okoliczności, pozwalających zorientować się o pełnym zakresie omawianego obowiązku. Abstrakcyjna analiza w tej sferze jest utrudniona, a przy tym mało efektywna, gdyż prowadzi z zasady do niedefinitywnych wniosków. Można co prawda wyodrębnić pewne obowiązki dość powszechnie spotykane w zobowiązaniach i rozpatrywać ich wyłączenie przy pozostawieniu ewentualnych pozostałych obowiązków, jednak trudno w ten sposób ocenić całość zmieniającej się w zobowiązaniu sytuacji. Przykładowo, abstrakcyjnie można by rozważać wprowadzenie postanowienia wyłączającego obowiązek lojalności wierzyciela. W doktrynie sformułowano wniosek o niedopuszczalności takiego rozwiązania zaznaczając, że „przyjęcie innego założenia oznaczałoby naruszenie relacji ukształtowanej pomiędzy stronami i przyjęcie możliwości swobodnego naruszania zobowiązania 
przez wierzyciela bez istnienia jakiejkolwiek sankcji z tym związanej”, ${ }^{37}$. Pomijając wątpliwości dotyczące samego pojęcia takiego obowiązku, jego istnienia i zakresu ${ }^{38}$, w zobowiązaniach, w których można by przyjąć jego występowanie (przy jednoczesnym braku szczegółowego przepisu wprowadzającego dany obowiązek, i to przepisu o charakterze imperatywnym, jak np. w art. 760 k.c.), należałoby zbadać całościową sytuację dłużnika, w jakiej się on znajduje w wyniku takiego wyłączenia. Można jednak pokusić się o wniosek, że takie postanowienie umowne mogłoby być dopuszczalne, gdyby nie prowadziło jednocześnie do obciążenia dłużnika wszelkimi konsekwencjami zachowania nielojalnego drugiej strony ${ }^{39}$ i gdyby nie pozbawiało go możliwości ochrony jego interesu w przypadku niewykonania przez niego zobowiązania z powodu nielojalnego zachowania wierzyciela, co zależne byłoby od treści konkretnego zobowiązania, kształtu postanowienia wyłączającego określony obowiązek wierzycielski i znaczenia zachowania wierzyciela dla wykonywania zobowiązania. Trudno natomiast przyjmować, że w każdym przypadku wyłączenia obowiązku lojalności zachodziłyby konsekwencje wskazywane w doktrynie.

c) Ogólnie ujmowany w przepisach obowiązek współdziałania wierzyciela przy wykonywaniu zobowiązania na gruncie konkretnego zobowiązania może przedstawiać się w różny sposób. Może on składać się z kilku obowiązków szczegółowych (np. dostarczenie określonych informacji przydatnych do wykonania zobowiązania, danie zaliczki, odbiór świadczenia), ale może także obejmować jeden tylko konkretny obowiązek (np. odbiór świadczenia). W przypadku kilku obowiązków szczegółowych sytuacja przy ograniczaniu zakresu współdziałania wydaje się prostsza, gdyż ograniczenie to może przyjąć postać wyłączenia jednego

\footnotetext{
${ }^{37}$ W. BORYSIAK, Komentarz do art. 354 k.c., [w:] Komentarz, red. K. Osajda, 2017, s. 76.

${ }^{38}$ Istnienie takiego obowiązku po stronie wierzyciela i jego zakres oraz charakter budzą wątpliwości i rozbieżne oceny. Czasami jest on postrzegany jako wyraz respektowania zasad współżycia społecznego przez wierzyciela przy współdziałaniu przy wykonywaniu zobowiązania (tak np. M. SAFJAN, Komentarz do art. 354 k.c., [w:] Komentarz, red. K. Pietrzykowski, 2018, art. 354 k.c., Nb 11). Przez niektórych jest natomiast traktowany jako dodatkowy, szczególny obowiązek, głównie po stronie dłużnika, występujący w niektórych typach zobowiązań (tak J. POKRZYwnIAK, Obowiązek lojalności jako element stosunku obligacyjnego, „Monitor Prawniczy” 2003, nr 19, s. 885 n.; P. MACHNiKowsKi, Struktura zobowiąania, s. 166-167). Obowiązek lojalnego zachowania czasami przewidywany jest wprost przez ustawodawcę, jak np. w art. 760 k.c. odnoszącym się do umowy agencyjnej.

${ }^{39}$ Uregulowanie umowne przewidujące przypisanie dłużnikowi odpowiedzialności za naruszenie zobowiązania spowodowane okolicznościami dotyczącymi wierzyciela uznawane jest za niedopuszczalne. Zob. P. KonIK, Umowne kształtowanie, s. 202-208; A. ŚMIEJA, Umowna modyfikacja zasad odpowiedzialności kontraktowej, „Iustitia” 2011, nr 3, s. 120; M. GuTOwsKI, Komentarz do art. 473 k.c., [w:] Komentarz, red. M. Gutowski, 2019, art. 473 k.c. Wyrok SN z 27.9.2013 r., I CSK 748/12, OSNC 2014/6/67; wyrok SA w Szczecinie z 25.3.2015 r., I ACa 847/14, LEX 1771374; wyrok SA w Lublinie z 11.6.2014 r., I ACa 136/14, LEX 1498953.
} 
lub kilku szczegółowych obowiązków przy zachowaniu przynajmniej jednego. $\mathrm{Tu}$ znaczenie miałby charakter danego wyłączanego obowiązku i wpływ zachowania objętego tym obowiązkiem na wykonywanie zobowiązania. Zauważalne jest możliwe zróżnicowanie poszczególnych obowiązków i różna ich ranga. W rezultacie, w odniesieniu do wyłączania niektórych $\mathrm{z}$ nich mogą uaktualniać się te same argumenty, które były istotne przy wyłączaniu obowiązku współdziałania w całości. Natomiast w przypadku, gdyby obowiązek współdziałania ograniczał się do jednego tylko obowiązku, ujawnia się pewna trudność, a mianowicie, czy dane zachowanie wierzyciela nadaje się w ogóle do ograniczenia, a w szczególności, czy można modyfikować jego zakres (rozmiar). Brak takiej możliwości wyłączałby możliwość ograniczania zakresu danego obowiązku i prowadził do sytuacji, że obowiązek ten mógłby zostać albo wyłączony w całości, albo pozostawiony. Wątpliwości widoczne są choćby w przypadku współdziałania przybierającego postać odbioru (przyjęcia) świadczenia. Z jednej strony można by postrzegać tę sytuację, jako zero-jedynkową, tj. taką, w której występuje albo przyjęcie świadczenia, albo jego brak. Dostrzegalna jest jednak możliwość stworzenia sytuacji pośredniej, kiedy przyjęcie świadczenia miałoby następować tylko w ściśle określonych okolicznościach. Oznaczałoby to wprowadzenie dodatkowych przesłanek odbioru świadczenia. W rezultacie wierzyciel miałby obowiązek jego przyjęcia tylko przy zaistnieniu owych dodatkowych okoliczności. Przykłady takich rozwiązań spotykane są w praktyce. Wskazać można choćby stosowane często w umowach o roboty budowlane zastrzeżenie, że inwestor ma obowiązek dokonania odbioru jedynie w przypadku świadczenia bezusterkowego, a więc zupełnego braku tych usterek w rezultacie wykonanych robót. Zaznaczyć jednak trzeba, że takie uregulowanie zostało zakwestionowane w orzecznictwie jako sprzeczne $\mathrm{z}$ kryterium natury zobowiązania $^{40}$, a konkretniej - jak można wywodzić z ogólnie sformułowanej wypowiedzi - jako wprowadzające nadmierną niepewność sytuacji wykonawcy robót, a także nierespektujące konstrukcji zobowiązania wzajemnego. Spostrzeżenie co do konsekwencji takiego zastrzeżenia umownego jest trafne.

\footnotetext{
${ }^{40}$ Wyrok SA w Białymstoku z 1.04.2019 r., I AGa 183/18, LEX 2693423, w którym zakwestionowano dopuszczalność zastrzeżenia umownego przewidującego, że roboty mogą być odebrane jedynie wówczas, gdy nie są obarczone jakimikolwiek usterkami z uwagi na jego sprzeczność z naturą stosunku zobowiązaniowego. Odwołano się w tym zakresie do wyrok SN z 21.04.2017 r., I CSK 333/16, w którego uzasadnieniu sformułowano pogląd: ,przyjmowanie bowiem, że każde odstępstwo od takiego idealnego stanu dawałoby inwestorowi prawo odmowy odebrania obiektu, pozostawałoby w sprzeczności z naturą zobowiązania objętego umową o roboty budowlane i naruszałoby równowagę między inwestorem a wykonawcą, pozostawiając tego ostatniego w niepewności odnośnie do należnego wynagrodzenia oraz zwrotu poniesionych wydatków".
} 
Można jednak dostrzec podstawę do przyjęcia jego sprzeczności także z kryterium ustawy, a mianowicie z imperatywną regulacją art. 647 k.c., który przewiduje obowiązek odbioru niepowiązany z jakimikolwiek kryteriami wartościującymi ten obowiązek. Zauważyć zresztą trzeba, że w wielu orzeczeniach ${ }^{41}$ sądy odwoływały się do treści art. 647 k.c. i przewidzianego w nim obowiązku odbioru robót przez inwestora (wierzyciela) jako ujętego ogólnie i nieodnoszącego się do wadliwości bądź niewadliwości tych robót, co w istocie opiera się na założeniu jego imperatywności właśnie.

W przypadku ograniczenia obowiązku współdziałania polegającego na ograniczeniu kryteriów, zgodnie z którymi to współdziałanie - według art. 354 § 1 k.c. W zw. z art. $354 \S 2$ k.c. - ma następować, strony mogłyby wyeliminować poszczególne kryteria, pozostawiając niektóre z nich. Mogłoby to przybierać postać wyraźnego wskazania tych, które wiązałyby strony, albo tych eliminowanych. Widoczna jest przy tym różna doniosłość poszczególnych kryteriów. Ustalone zwyczaje oraz społeczno-gospodarczy cel zobowiązania wydają się mieć mniejsze znaczenie niż kryterium zasad współżycia społecznego. Przypomnieć trzeba, że ze względu na to ostatnie kryterium w doktrynie sformułowano pogląd o niedopuszczalności wyłączenia obowiązku współdziałania wierzyciela, gdyż wyłączenie obowiązku współdziałania w sposób zgodny z zasadami współżycia społecznego samo musiałoby zostać uznane za sprzeczne $\mathrm{z}$ tym kryterium ${ }^{42}$, co zostało jednak zakwalifikowane jako zbyt kategoryczne. Generalnie rzecz ujmując, ingerencja umowna $w$ tę sferę i wyłączanie poszczególnych kryteriów ma mniejszy wpływ na zakres wierzycielskiego obowiązku współdziałania, niż ingerencja w pierwszą sferę. Ryzyko nieważności takiej regulacji umownej jest przez to zdecydowanie mniejsze.

O ograniczaniu obowiązku współdziałania wierzyciela przy wykonywaniu zobowiązania można mówić w jeszcze jednym aspekcie, a mianowicie co do zakresu należytej staranności wymaganej od wierzyciela przy tych czynnościach. Wprawdzie zachodzi wątpliwość, czy wierzyciel w ogóle podlega wymaganiom co do należytej staranności, wszak art. 355 k.c. odnosi się tylko do staranności wymaganej od dłużnika i brak przepisu odnoszącego się odrębnie do wierzyciela, jednak trudno przyjmować, że wobec tego nie jest od niego wymagana jakakolwiek staranność. Jej rozmiar nie jest uregulowany, ale istniejąca luka może zostać wypełniona przez regulację art. 355 k.c. Przepis

\footnotetext{
${ }^{41}$ Zob. wyrok SA w Białymstoku z 1.04.2019 r., I AGa 183/18, LEX 2693423; wyrok SN z 23.08. 2012 r., II CSK 21/12, LEX nr 1222148; wyrok SA w Białymstoku z 30.05.2014 r., I A Ca 124/14, LEX nr 1489028; wyrok SA w Gdańsku z 24.02.2012 r., V ACa 198/12, POSAG 2012/3/16-28.

${ }^{42}$ W. BORYSIAK, Komentarz do art. 354 k.c., [w:] Komentarz, red. K. Osajda, 2017, s. 77.
} 
ten dotyczy wprawdzie dłużnika, ale regulacja poziomu należytej staranności ma charakter bardziej uniwersalny i nadaje się do odniesienia do wierzyciela ${ }^{43}$. Zaakceptowanie tego wniosku otwiera drogę do rozważań dotyczących umownego kształtowania zakresu należytej staranności wierzyciela. W obecnym stanie regulacji ograniczanie tej staranności w stosunku do poziomu tej staranności wynikającego z art. 355 k.c. stosowanego per analogiam, należy uznać za dopuszczalne. Kwestią otwartą pozostaje zaś sposób ujęcia (zredagowania) tego ograniczenia, co może okazać się zadaniem niełatwym, skoro ujęcie kodeksowe jest ogólne, a konkretyzacja poziomu staranności może nastąpić dopiero na gruncie konkretnego zobowiązania. Regulacja umowna prowadząca do ograniczenia rozmiaru staranności wierzyciela musiałaby zatem zostać poprzedzona dokładną analizą zakresu tej staranności, który stanowiłby punkt odniesienia do regulacji umownej.

\section{UMOWNE PRZERZUCENIE NA DEUŻNIKA OBOWIĄZKU ZACHOWANIA OBJĘTEGO PIERWOTNIE OBOWIĄZKIEM WIERZYCIELSKIEGO WSPÓŁDZIAŁANIA}

Brak wyraźnej podstawy ustawowej do przyjęcia wniosku, że wyłączenie lub ograniczenie wierzycielskiego obowiązku współdziałania przy wykonywaniu zobowiązania prowadzi automatycznie do tego, że obowiązki dotychczas obciążające wierzyciela zostają w całości przerzucone na dłużnika, który w ten sposób staje się zobowiązany do ich wykonania zamiast wierzyciela. Taki wniosek trudno byłoby zasadnie wyprowadzać także pośrednio z regulacji kodeksowych; w szczególności z art. 355 k.c. przewidującego poziom należytej staranności wymaganej od dłużnika przy wykonywaniu zobowiązania. Trzeba jednak przyznać, że należyta staranność w jakimś stopniu kształtuje i uszczegóławia zachowania dłużnika stanowiące wykonywanie jego obowiązków. Powoduje ona także, że dłużnik przy wykonywaniu zobowiązania powinien w pewnym stopniu (wyznaczanym przez kryteria z art. 355 k.c.) radzić sobie z przeciwnościami pochodzącymi ze sfery zewnętrznej ${ }^{44}$. Przy niektórych zobowiązaniach, a mianowicie tych, przy których świadczenie jest związane ze sferą zależną czy dotyczącą wierzyciela, należyta staranność może czasami wymuszać

\footnotetext{
${ }^{43}$ Tak Z. BANASZCZYK, Komentarz do art. 362 k.c., [w:] Komentarz, red. K. Pietrzykowski, art. 362 k.c., Nb 17; P. KoniK, Umowne ksztattowanie, s. 203. Odmiennie M. LEMKOwSKI, Komentarz do art. 486 k.c., [w:] Komentarz, red. M. Gutowski, 2019, art. 486, Nb 10.

${ }^{44}$ P. KonIK, Umowne ksztattowanie, s. 195.
} 
radzenie sobie również z pewnymi okolicznościami dotyczącymi wierzyciela (np. pewne niedogodności przy usługach ochrony mienia czy osoby wierzyciela, usługach doradczych, medycznych czy także prawniczych). Spostrzeżenie to jest o tyle znaczące, że współdziałanie wierzyciela z natury swej dotyczy tej właśnie sfery. Wykonywanie przez dłużnika pewnych czynności mieszczących się pierwotnie w ramach współdziałania wierzyciela nie jest więc wykluczone. To, w jakim zakresie mogłoby to nastąpić, zależałoby jednak od charakteru tych czynności, a zwłaszcza od tego, czy miałyby one charakter osobisty i zastępowalny, czy nie. Znaczenie miałby tu także sposób określenia samego świadczenia obciążającego dłużnika. Przedstawienie go ogólnie (np. skutkowo) prowadziłoby do tego, że brak wyraźnego przypisania oznaczonych czynności wierzycielowi, mógłby uzasadniać przyjęcie, że wszystkie zachowania funkcjonalnie powiązane ze sobą, a prowadzące do tego celu mogłyby obciążać dłużnika. Sytuacja nie byłaby natomiast tak wyrazista, gdyby strony wskazały konkretne zachowania dłużnika składające się finalnie na świadczenie. W takim razie trudniej byłoby przyjąć, że dłużnik obowiązany jest wykonać wszelkie czynności, a więc także te, które miał wykonać wierzyciel.

W pewnym zakresie dłużnik mógłby więc być zmuszony do uzupełnienia swoim zachowaniem braku zachowania wierzyciela. Ustalenie tego zakresu możliwe byłoby jednak dopiero na gruncie konkretnego przypadku (konkretnego zobowiązania) i zależałoby każdorazowo od rodzaju i charakteru czynności objętych wierzycielskim obowiązkiem współdziałania. Kryteria te miałyby także znaczenie, gdyby strony, przewidując trudności przy wykonywaniu zobowiązania, chciały umownie uregulować to zagadnienie. Kwestia umownego kształtowania tej sfery będzie przedmiotem kilku szczegółowych uwag, które będą miały znaczenie także przy ustalaniu, które czynności nie mogą obciążać dłużnika, również przy braku regulacji umownej.

Kształtując postanowienia umowne w omawianej sferze, strony za każdym razem stawałyby przed pytaniem co do dopuszczalności rozwiązania, polegającego na przeniesieniu wierzycielskiego obowiązku współdziałania na dłużnika, czy inaczej: ciężaru starań o wykonanie zobowiązania w całości na dłużnika ${ }^{45}$. Już choćby pobieżna analiza tego zagadnienia pozwala bowiem dostrzec możliwość zaistnienia rozwiązań sprzecznych z właściwością (naturą) zobowiązania. Regulacja umowna prowadzi tu bowiem do ingerencji w konstrukcję zobowiązania opartą, między innymi, na wyodrębnieniu różnych ról poszczególnych stron stosunku zobowiązaniowego. Choćby z tego powodu można by pokusić się o ogólne spostrzeżenie, że charakter zobowiązania opiera się na wyodrębnieniu

\footnotetext{
${ }^{45}$ Tak P. MAChNiKowski, Treść umowy, s. 572-573, Nb 21.
} 
tych ról oraz przypisanych im obowiązków i uprawnień, i nie można umownie kształtować go w sposób powodujący zaburzenia tych ról. Nie znaczy to jednak, że jakakolwiek ingerencja w tę sferę musiałaby zostać uznana za niedopuszczalną i prowadzącą do naruszenia właściwości zobowiązania.

Pomimo tego, że z natury swej obowiązek współdziałania dotyczy zachowań wierzyciela związanych z jego sferą okoliczności, tj. okoliczności od niego zależnych czy jego dotyczących (takie wydaje się zresztą uzasadnienie wprowadzenia tego obowiązku), w ramach tych zachowań można wyodrębnić takie, które bez problemu mogą być realizowane przez dowolną osobę czy dowolną stronę zobowiązania. Przykładem mogą być choćby przypadki regulowane wyraźnie w kodeksie cywilnym. Na gruncie art. $454 \S 1$ k.c. w odniesieniu na przykład do miejsca wykonania zobowiązania ze świadczeniem niepieniężnym to wierzyciel, celem odbioru przedmiotu świadczenia, udaje się do miejsca zamieszkania lub siedziby dłużnika z chwili powstania zobowiązania. Strony mogą jednak ustalić odmiennie, tj. że to dłużnik pokona tę drogę do siedziby wierzyciela. Przywołać można także kwestię obowiązku dostarczenia materiałów do wykonania dzieła (art. 633 k.c.), która może być dowolnie uregulowana w umowie. Można także wskazać przykład z dostarczeniem przy robotach budowlanych projektu przez wykonawcę, a nie przez inwestora, jak to wynika z art. 647 k.c., choć kwestia ta budzi wątpliwości ${ }^{46}$. Przy umowach, przy których istotne znaczenie mają informacje potrzebne do wykonania określonej usługi, informacje te mogą być dostarczone przez wierzyciela, ale dłużnik może także - ze względu na powszechną dostępność tych danych - pozyskać je samodzielnie. Czynności te nie mają charakteru osobistego i są zastępowalne (możliwe do zastąpienia aktywnością drugiej strony), zatem nie ma przeszkody dla przejęcia ich do wykonania przez dłużnika.

Występują również takie zachowania wierzyciela, które mają charakter ściśle osobisty, a w rezultacie nie mogą być dokonywane przez kogokolwiek. W szczególności można wymienić te, które związane są z określonym dobrem pozostającym w wyłącznej dyspozycji wierzyciela lub możliwym do zdobycia wyłącznie przez niego, a także te, które związane są ściśle z osobą wierzyciela, czy uzależnione wyłącznie od woli lub uznania wierzyciela (jego oceny, akceptacji). $\mathrm{Z}$ uwagi na charakter świadczenia i treść zobowiązania nie mogłyby one być

\footnotetext{
${ }^{46}$ Konstrukcje takie spotykane są w praktyce oraz dość powszechnie akceptowane w doktrynie - zob. B. LACKOROŃSKI, Komentarz do art. 647 k.c., [w:] Kodeks cywilny. Komentarz. Zobowiazania. Część ogólna, t. III B, red. K. Osajda, Warszawa: C.H. Beck 2017, art. 647 k.c., t. 22 oraz podana tam literatura. Zob. jednak wątpliwości z tym związane dotyczące znaczenia współdziałania wierzyciela dla kwalifikacji umowy o roboty budowlane J.A. STRZĘPKA, Umowa o roboty budowlane, s. 1438-1445 i podane tam orzecznictwo oraz literatura.
} 
dokonywane przez kogokolwiek. Nawet jeżeli ktoś inny mógłby dokonać podobnej czynności (czynności zaliczanej do tej samej kategorii), nie musiałyby one być porównywalne z czynnościami wierzyciela ani ich zastąpić (np. obowiązek udostępnienia określonego miejsca, udzielenia wskazówek co do parametrów świadczenia). Podobnie przy odbiorze świadczenia, to że byłoby ono akceptowalne dla innej osoby, grupy osób czy nawet obiektywnie, nie musiałoby oznaczać tego samego dla wierzyciela. Gdyby doprowadzić do przerzucenia obowiązku tego typu zachowań na dłużnika, oznaczałoby to, że dłużnik musi w jakiś sposób uzyskać dostęp do tych dóbr, informacji czy osoby wierzyciela w wyniku wyłącznie własnego zachowania i bez udziału wierzyciela. Zakładałoby to jednak konieczność wkroczenia w sferę wierzyciela i konieczność zastąpienia go, co z uwagi na charakter wspomnianych zachowań należałoby uznać za niewykonalne (często niemożliwe) a także nieracjonalne ${ }^{47}$. Byłoby więc sprzeczne $\mathrm{z}$ właściwością zobowiązania, które cechuje, między innymi, racjonalność. Spostrzeżenie to wsparte jest także przez argument, że kształtując odpowiedzialność dłużnika za naruszenie zobowiązania strony, nie mają możliwości ustalić, że ponosi on odpowiedzialność także za okoliczności dotyczące wierzyciela ${ }^{48}$. Przerzucenie na dłużnika obowiązku zachowań ściśle osobistych prowadziłoby zaś do tego, że dłużnik naruszając zobowiązanie w tym zakresie, odpowiadałby za okoliczności ze sfery ściśle powiązanej z wierzycielem.

Należy także dostrzec, że niektóre zachowania wierzyciela stanowiące jego współdziałanie są ściśle powiązane z jego rolą w zobowiązaniu nawet niezależnie od charakteru świadczenia i treści zobowiązania. Taką czynnością jest odbiór świadczenia. Za truizm należałoby uznać stwierdzenie, że cechą zobowiązania jest, iż to dłużnik spełnia świadczenie, a jego odbioru dokonuje wierzyciel. Warto jednak to podkreślić, podobnie jak to, że odbiór świadczenia jest związany z wierzycielem, bo w ten sposób dokonuje on akceptacji i oceny świadczenia $^{49}$, a to przecież o zaspokojenie jego interesu przez świadczenie chodzi w zobowiązaniu. Przerzucenie obowiązku odbioru świadczenia na dłużnika prowadziłoby więc do pomieszania ról w zobowiązaniu, dłużnik jako ten, który

\footnotetext{
${ }^{47}$ Mogłoby także prowadzić do dalszych negatywnych konsekwencji. Na przykład dłużnik chcąc wykonać zobowiązanie mógłby narazić się na roszczenia posesoryjne wierzyciela, próbując wejść na jego nieruchomość, której dotyczy świadczenie (tak M. LEMKOwSKI, Komentarz do art. 486 k.c., [w:] Komentarz, red. M. Gutowski, 2019, art. 486, Nb 5).

${ }^{48}$ Zob. A. ŚMIEJA, Umowna modyfikacja, s. 120; M. GuTOwSKI, Komentarz do art. 473 k.c., [w:] Komentarz, red. M. Gutowski, 2016, art. 473 k.c.; P. KonIK, Umowne ksztattowanie, s. 202-208. Wyrok SN z 27.9.2013 r., I CSK 748/12, OSNC 2014/6/67; wyrok SA w Szczecinie z 25.3.2015 r., I ACa 847/14, LEX 1771374; wyrok SA w Lublinie z 11.6.2014 r., I ACa 136/14, LEX 1498953.

${ }^{49} \mathrm{Z}$ tego powodu można mówić o odbiorze jako czynności akceptacyjnej. Zob. P. KonIK, Odbiór robót, s. 59-60; F. Zoll, Rękojmia. Odpowiedzialność sprzedawcy, Warszawa: C.H. Beck 2018, s. 138.
} 
spełnia świadczenie, miałby jednocześnie oceniać jego prawidłowość i zgodność $\mathrm{z}$ treścią zobowiązania, a tym samym o zgodności jego z interesem drugiej strony $^{50}$. Odnośnie do odbioru świadczenia trzeba jednak zaznaczyć, że pomimo tego strony umownie mogłyby przewidzieć sytuację równorzędną z odbiorem, tj. ze skutkami odbioru przy braku aktywności wierzyciela ${ }^{51}$. Na tej podstawie można poczynić ogólniejsze spostrzeżenie, że o ile nałożenie na dłużnika obowiązków podjęcia zachowań ściśle związanych z rolą wierzyciela należałoby uznać za niedopuszczalne, to do rozważenia nadaje się wprowadzenie rozwiązania polegającego na przyznaniu dłużnikowi możliwości jednostronnego wypełnienia luki, wynikającej z braku współdziałania wierzyciela (np. uprawnienie do oznaczenia właściwości świadczenia). Nie byłoby to więc ściśle przerzucenie na dłużnika obowiązków wierzyciela, ale możliwość stworzenia przez dłużnika stanu równorzędnego z tym, jaki by istniał, gdyby wierzyciel jednak swoje obowiązki wykonał, albo przyjęcie - bez potrzeby aktywności dłużnika - fikcji, że dany istniejący stan jest tym, który jest wynikiem zachowania wierzyciela. Kwestia ta wymaga jednak każdorazowej analizy $\mathrm{z}$ uwzględnieniem charakteru danego zachowania i jego wpływu na wykonywanie zobowiązania przez dłużnika.

Ścisły związek niektórych obowiązków z wierzycielem nie pozwala zatem na ich przerzucenie na dłużnika, co nie musi wykluczać dopuszczalności ich wyłączenia.

\section{PODSUMOWANIE}

Powyższe rozważania prowadzą do wniosku, że ocena dopuszczalności wyłączenia obowiązku wierzycielskiego współdziałania przy wykonywaniu zobowiązania nie przedstawia się jednoznacznie, a analizie towarzyszą poważne wątpliwości, które wskazują duży stopień skomplikowania tej materii. Wątpliwości owe dotyczą już choćby podstawowej kwestii, a mianowicie, czy wyłączeniu ogólnego obowiązku współdziałania wynikającego z art. 354 § 2 k.c. sprzeciwia się kryterium ustawy. Ważąc poszczególne argumenty za i przeciw, za bardziej właściwy wydaje się wniosek o braku takiej sprzeczności. Kryterium to może mieć natomiast znaczenie przy obowiązkach wynikających $\mathrm{z}$ przepisów

\footnotetext{
${ }^{50} \mathrm{Z}$ sytuacją taką mamy do czynienia w przypadku postanowień umownych spotykanych w umowach o roboty budowlane bądź o dzieło, przewidujących, że w przypadku braku przystąpienia wierzyciela do odbioru robót bądź dzieła, odbioru takiego dokona jednostronnie dłużnik.

${ }^{51}$ Zob. P. KonIK, Odbiór robót, s. 62.
} 
szczególnych, a także w stosunkach konsumenckich. Większym znaczeniem może się cechować kryterium właściwości (natury) zobowiązania, które, ze względu na specyficzne rozwiązanie umowne przyjęte przez strony, pozwala wziąc pod uwagę, czy nie sprzeciwia się ono takim cechom zobowiązania, jak zapewnienie ochrony uzasadnionym interesom dłużnika, brak nadmiernego uzależnienia go od wierzyciela, czy racjonalność zobowiązania. Także to kryterium nie pozwala na przyjęcie wniosku o generalnej niedopuszczalności wyłączenia ogólnego obowiązku współdziałania (wyrażonego w art. 354 § 2 k.c.) i dopiero skrajne rozwiązania, pozostające w sprzeczności ze wskazanymi cechami, zasługiwałyby na taką ocenę. Strony mają więc pewną dozę swobody umownej w sferze dotyczącej kształtowania zakresu tego obowiązku.

W przypadkach, w których wyłączenie obowiązku współdziałania byłoby dopuszczalne, dopuszczalne byłoby także ograniczenie zakresu współdziałania. To zaś mogłoby przybrać postać wyłączenia niektórych obowiązków przy pozostawieniu pozostałych, albo, w przypadku współdziałania sprowadzającego się do jednego obowiązku, zmniejszenia jego rozmiaru, o ile obowiązek ten (jego rozmiar) dawałby się stopniować. Poza ograniczaniem rozmiaru obowiązku współdziałania, ograniczenie mogłoby się odnosić do kryteriów wskazanych w art. $354 \S 1$ w zw. z art. $354 \S 2$ k.c., określających sposób współdziałania, które mogłyby podlegać redukcji, z tym zastrzeżeniem, że redukcja obejmująca kryterium społeczno-gospodarczego celu czy zwyczaju byłaby mniej ryzykowna, niż redukcja kryterium zasad współżycia społecznego.

Zdjęcie z wierzyciela obowiązku współdziałania nie powoduje, że ciężar starań o wykonanie zobowiązania przechodzi w całości na dłużnika i to on musi podjąć wszystkie zachowania wcześniej ciążące na wierzycielu. Część tych zachowań dłużnik musiałby jednak wykonać w ramach należytej staranności, szczególnie przy ogólnym (zwłaszcza skutkowym) ujęciu świadczenia obciążającego dłużnika. Strony mogłyby tę kwestię regulować umownie i przypisywać dłużnikowi poszczególne zachowania obciążające wcześniej wierzyciela, regulacja taka mogłaby się jednak okazać skuteczna tylko w odniesieniu do czynności, które nie miałyby charakteru osobistego, niezastępowalnego.

\section{BIBLIOGRAFIA}

ŹRÓDŁA PRAWA

Ustawa z dnia 23 kwietnia 1964 r. - Kodeks cywilny, t.j. Dz.U. 2020, poz. 1740. 


\section{LITERATURA}

BANASZCZYK Zbigniew: Komentarz do art. 362 k.c., [w:] Komentarz. Kodeks cywilny, t. I, red. K. Pietrzykowski, Warszawa: C.H. Beck 2018, Nb 1-32.

BŁACHUTA Franciszek: Komentarz do art. 354 k.c., [w:] Kodeks cywilny. Komentarz, t. II, red. Z. Resich, Warszawa: Wydawnictwo Prawnicze 1972, s. 847-849.

BORYSIAK Witold: Komentarz do art. 354 k.c., [w:] Kodeks cywilny. Komentarz. Zobowiązania. Część ogólna, t. III A, red. K. Osajda, Warszawa: C.H. Beck 2017, s. 62-79.

GAWRYSIAK Marian: Wina jako przesłanka zwłoki wierzyciela, „Ruch Prawniczy, Ekonomiczny i Socjologiczny" 1979, nr 1, s. 43-55.

GuTOwski Maciej: Komentarz do art. 354 k.c. oraz art. 473 k.c., [w:] Kodeks cywilny, t. II: Komentarz. Art. 353-688, red. M. Gutowski, Warszawa: C.H. Beck 2019, Nb 1-41, Nb 1-25.

KLEIN Alfred: Elementy zobowiązaniowego stosunku prawnego, Wrocław: PWN 1980.

KLEIN Alfred: Wykonanie umowy i odpowiedzialność, [w:] Instytucje prawne w gospodarce narodowej, red. L. Bar, Wrocław-Warszawa-Kraków-Gdańsk-Łódź: Ossolineum 1981, s. 266-310.

KLEIN Alfred: Skutki prawne braku współdziałania wierzyciela z dłużnikiem, „Acta Universitatis Wratislaviensis", Prawo, 1990, t. CLXXXVI, nr 1152, s. 143-165.

KonIK Piotr: Odbiór robót budowlanych - zagadnienia wybrane, „Studia Prawa Prywatnego” 2016, z. 2, s. 57-66.

KonIK Piotr: Umowne kształtowanie odpowiedzialności dłużnika za naruszenie zobowiązania w polskim prawie cywilnym, Warszawa: C.H. Beck 2019.

LACKOROŃSKI Bogusław: Komentarz do art. 647 k.c., [w:] Kodeks cywilny. Komentarz. Zobowiązania. Część ogólna, t. III B, red. K. Osajda, Warszawa: C.H. Beck 2017, T. 1-63.

LeMKowski Marcin: Komentarz do art. 486 k.c., [w:] Kodeks cywilny, t. II: Komentarz. Art. 353-688, red. M. Gutowski, Warszawa: C.H. Beck 2019, Nb 1-27.

MAChNIKOwSKi Piotr: Komentarz do art. 354 k.c., [w:] Kodeks cywilny. Komentarz, red. E. Gniewek, P. Machnikowski, Warszawa: C.H. Beck 2016, Nb 1-10.

MAchNikowski Piotr: Struktura zobowiązania; Treść umowy, [w:] System Prawa Prywatnego, t. V: Prawo zobowiązań - część ogólna, red. K. Osajda, Warszawa: C.H. Beck 2020, s. 131-191, 564-647.

POKRZYwniAK Jakub: Obowiązek lojalności jako element stosunku obligacyjnego, „Monitor Prawniczy" 2003, nr 19, s. 885-898.

RADWAŃSKI Zbigniew: Zobowiązania - część ogólna, Warszawa: C.H. Beck 2003.

SAFJAn Marek: Komentarz do art. 354 k.c., [w:] Komentarz. Kodeks cywilny, t. I, red. K. Pietrzykowski, Warszawa: C.H. Beck 2015, Nb 1-15.

STRZĘPKA Janusz: Umowa o roboty budowlane, [w:] System Prawa Handlowego, t. V: Prawo umów handlowych, red. M. Stec, Warszawa: C.H. Beck 2017, s. 1395-1586.

ŚMIEJA Andrzej: Umowna modyfikacja zasad odpowiedzialności kontraktowej, „Iustitia” 2011, nr 3, s. $117-124$.

TRZASKOwSKI Roman: Granice swobody kształtowania treści i celu umów obligacyjnych. Art. $353^{1}$ k.c., Kraków: Zakamycze 2005.

ZoLl Fryderyk: Wykonanie i skutki niewykonania lub nienależytego wykonania zobowiązań, [w:] System Prawa Prywatnego, t. VI: Prawo zobowiązań - część ogólna, red. A. Olejniczak, Warszawa: C.H. Beck 2016, s. 1046-1276.

ZoLl Fryderyk: Rękojmia. Odpowiedzialność sprzedawcy, Warszawa: C.H. Beck 2018, s. 138. 


\section{UMOWNE WYŁACZANIE I OGRANICZANIE \\ WIERZYCIELSKIEGO OBOWIAZZKU WSPÓŁDZIAŁANIA \\ PRZY WYKONYWANIU ZOBOWIĄZANIA}

\section{Streszczenie}

Artykuł obejmuje rozważania dotyczące odpowiedzi na pytanie, czy strony zawierając umowę mogą wyłączyć bądź ograniczyć wierzycielski obowiązek współdziałania z dłużnikiem przy wykonywaniu zobowiązania, który wynika z art. 354 § 2 Kodeksu cywilnego. Rozważania te prowadzone są z uwzględnieniem przewidzianych w art. 3531 Kodeksu cywilnego kryteriów kształtujących swobodę umów. W konsekwencji dostrzeżenia pewnego zakresu swobody kontraktowej w tej sferze, uwagę skierowano także na dopuszczalność przerzucenia przez strony w umowie wierzycielskiego obowiązku współdziałania na dłużnika.

Słowa kluczowe: swoboda umów; wykonywanie zobowiązania; właściwość (natura) zobowiązania; zasady współżycia społecznego

\section{CONTRACTUAL EXCLUSION AND LIMITATION \\ OF THE CREDITOR'S OBLIGATION TO COOPERATE IN PERFORMING THE OBLIGATION}

\section{Summary}

The article includes considerations regarding the answer to the question whether the parties concluding the contract may exclude or limit the creditor's obligation to cooperate with the debtor in the performance of the obligation which arise from art. $354 \S 2$ of the Civil Code. These considerations are carried out taking into account the criteria determining freedom of contract shown in Article 3531 of the Civil Code. As a consequence of noticing a certain scope of contractual freedom in this area, attention was also paid to the admissibility of a contractual transfer on debtor the creditor's obligation to cooperate in performing the obligation.

Key words: freedom of contracts; performance of obligations; nature of obligations; principles of social co-existence 